NBER WORKING PAPER SERIES

\title{
TURNING WORKERS INTO SAVERS? INCENTIVES, LIQUIDITY, AND CHOICE IN 401(K) PLAN DESIGN
}

\author{
Olivia S. Mitchell \\ Stephen P. Utkus \\ Tongxuan (Stella) Yang \\ Working Paper 11725 \\ http://www.nber.org/papers/w11725 \\ NATIONAL BUREAU OF ECONOMIC RESEARCH \\ 1050 Massachusetts Avenue \\ Cambridge, MA 02138 \\ October 2005
}

The authors thank John Ameriks, Sarah Holden and participants at the NBER Personnel Economics Summer Institute for helpful comments. They are also grateful to Vanguard for the provision of recordkeeping data under restricted access conditions; and to the Pension Research Council at the Wharton School and the Bradley Foundation for research support. This research is part of the NBER programs on Aging and Labor Economics. Opinions expressed herein are those of the authors alone, and not those of The Wharton School, Vanguard, or any other institution which whom the authors may be affiliated. (02005 Mitchell, Utkus, and Yang. The views expressed herein are those of the author(s) and do not necessarily reflect the views of the National Bureau of Economic Research.

(C2005 by Olivia S. Mitchell, Stephen P. Utkus, and Tongxuan (Stella) Yang. All rights reserved. Short sections of text, not to exceed two paragraphs, may be quoted without explicit permission provided that full credit, including (C) notice, is given to the source. 
Turning Workers into Savers? Incentives, Liquidity, and Choice in 401(k) Plan Design Olivia S. Mitchell, Stephen P. Utkus, and Tongxuan (Stella) Yang

NBER Working Paper No. 11726

October 2005

JEL No. J26, J32, G23

\section{ABSTRACT}

We develop a comprehensive model of 401(k) pension design that reflects the complex tax, savings, liquidity and investment incentives of such plans. Using a new dataset on some 500 plans covering nearly 740,000 workers, we show that employer matching contributions have only a modest impact on eliciting additional retirement saving. In the typical 401(k) plan, only 10 percent of non-highlycompensated workers are induced to save more by match incentives; and 30 percent fail to join their plan at all, despite the fact that the company-proffered match would grant them a real return premium of 1-5\% above market rates if they contributed. Such indifference to retirement saving incentives cannot be attributed to liquidity or investment constraints. These results underscore the need for alternative approaches beyond matching contributions, if retirement saving is to become broaderbased.

Olivia S. Mitchell

Department of Insurance and Risk Management The Wharton School University of Pennsylvania 3620 Locust Walk Suite 3000-SHDH Philadelphia, PA 19104 and NBER mitchelo@wharton.upenn.edu

Stephen P. Utkus Principal, Vanguard Center for Retirement Research 100 Vanguard Boulevard, M38 Malvern, PA 19355 steve_utkus@vanguard.com
Tongxuan (Stella) Yang

Pension Research Council The Wharton School University of Pennsylvania 3620 Locust Walk, Suite 3000-SHDH Philadelphia, PA 19104 tongxuan@wharton.upenn.edu 


\section{Turning Workers into Savers? Incentives, Liquidity, and Choice in 401(k) Plan Design}

Company-sponsored defined contribution (DC) plans are at the core of the US retirement system today, with nearly 60 million private sector employees participating in DC plans holding $\$ 2.5$ trillion in assets. ${ }^{1}$ Workers covered by a 401(k) plan throughout their working careers can anticipate replacement incomes of nearly 60 percent from their 401(k) plan alone (Holden and VanDerhei, 2005), and for the Baby Boom generation, company-based DC plans are expected to provide larger retirement benefits than Social Security (Poterba et al., 2001). Against this optimistic backdrop, however, some experts have expressed concern that workers may fail to properly exercise the new responsibilities imposed on them by participant-directed DC plans, particularly if they fail to join their 401(k) plans, save inadequately, overly concentrate their portfolios in a single asset, or spend their retirement savings too quickly. ${ }^{2}$

Prior research has largely focused on how employer matching contributions in 401(k) plans shape employee saving behavior. ${ }^{3}$ In this paper, we develop a more comprehensive model of the incentives inherent in 401(k) plan design. Our research is made possible by a rich dataset on several hundred 401(k) plans covering nearly 740,000 employees that contains unique detail on plan design and firm and workforce characteristics. Not only are we able to model employer matching

\footnotetext{
${ }^{1}$ The number of DC participants has grown in the US at an annual $3 \%$ rate over the past two decades, almost double the rate of labor force increase. Today there are three times as many workers participating in DC plans as defined benefit (DB) plans. Since 1985, the number of DB plan participants has declined by $8 \%$ annually and these plans hold fewer assets than in DC plans (DB assets are estimated at \$2.2 trillion; Vanguard, 2004).

${ }^{2}$ For reviews of employee behavior in DC plans see Choi et al. (2004) and Munnell and Sunden (2004). Engelhardt and Kumar (2003) contains an excellent schematic summary.

${ }^{3}$ In this paper, we use the term "401(k)" plan to include both 401(k) and 403(b) salary deferral plans. The former are offered in the corporate sector, while the latter are offered by non-profit employers; both terms are derived from the section of the US tax code permitting contributions to these retirement plans to be tax-qualified under particular conditions (McGill et al. 2004). Our analysis excludes governmental plans (e.g. so-called Section 457 plans). More than $70 \%$ of US DC plans are 401(k)-type programs and $85 \%$ of DC plan participants have a $401(\mathrm{k})$ feature.
} 
contributions with exceptional precision, but we are also able to capture liquidity, tax, and investment constraints inherent in modern 401(k) plan design.

As we detail below, a complex set of incentives and constraints shapes 401(k) offerings and employee saving in these plans. Salary deferrals deposited in 401(k) plans typically provide workers with a current tax benefit, though the tax code limits the amount of tax deferral for highly-paid employees via contribution and nondiscrimination testing limits. Also, 401(k) saving is fairly illiquid: participants may not deplete their retirement accounts while working for their current employer, and if they do change jobs and spend the money before retirement, they owe income and penalty taxes. Nevertheless many plans offer a loan feature, whereby participants may borrow up to half their plan balance (up to $\$ 50,000$ ) with no tax consequences. ${ }^{4}$ Also the typical $401(\mathrm{k})$ plan offers a restricted set of investment choices, so participants generally face a constrained investment menu compared to retail mutual fund or brokerage accounts. Offsetting this limitation is the fact that employer tend to offer a saving incentive known as the "match;" in practice, these vary from zero to more than six percent of pay, with the median employer offering a match equivalent to three percent of pay.

In this paper, we seek to explain in detail how the incentives embedded in 401(k) plans influence saving outcomes. Specifically, our objective is to measure saving behavior induced by 401(k) plan design features including the structure of the employer match, the presence of loans, and the investment menu design, and to differentiate these effects from saving patterns attributable to workers' own preferences or firm-specific characteristics. Our perspective is that of the plan sponsor, and so our unit of analysis is the 401(k) plan as a whole, rather than individual employees.

\footnotetext{
${ }^{4}$ At the time of job change or retirement, a participant may typically access the vested balance of his DC plan account, incurring taxes and possibly a $10 \%$ if under age $59 \frac{1}{2}$.
} 
Our empirical results are striking. In contrast to previous studies that focused on one or a handful of plans, our much larger cross-plan analysis shows that the incentive effects of employer matching contributions are relatively minimal, particularly for non-highly-compensated workers (tax law defines this group as workers earning less than $\$ 85,000$ in 2001). We estimate that in a typical plan, some 60 percent of non-highly compensated workers would participate in a taxdeferred saving plan independent of the employer match; only about 10 percent more would respond to match incentives and join the plan as a result; and the remaining 30 percent or so would fail to participate, despite the availability of an employer match. The failure of many employees to participate is remarkable, given that the most prevalent employer matching formulas offer workers an implicit annual real rate of return premium on their contributions of 1-5 percent above the expected return on 401(k) investments. After controlling for differences in employee demographics, we estimate that the average workforce forfeits about half of the company-promised match.

Lack of responsiveness to 401(k) savings incentives does not appear to be attributable to pension plan liquidity or investment menu constraints. While relaxing these constraints can influence behavior, the response magnitudes are second-order and tend to be contradictory. Offering workers a larger choice of investment funds does broaden plan participation, but including more equity funds in the mix discourages participation. Providing greater liquidity through a loan feature has no impact on plan participation, but it does raise plan contribution by about 10 percent among non-highly-paid participants. In all, we conclude that loan and investment constraints are not binding enough to explain why non-participants appear reluctant to join their employer's 401(k) plan.

More broadly, our results imply that matching contributions are of limited usefulness as an incentive to induce many workers to save for retirement. The fact that only 10 percent of eligible workers responds to, and nearly 30 percent fails to respond to, substantial return premiums on 
contributions underscores the difficulty of expanding retirement saving through such mechanisms. Such contributions can be a useful form of compensation: that is, workers who do participate in their $401(\mathrm{k})$ plans receive a benefit equivalent to $2 \%$ of the employer's wage bill, on average. But matching contributions have a modest effect as an inducement for saving: they do little to turn workers into savers. As a result, policymakers or plan sponsors seeking to enhance the reach of company pension coverage beyond current levels might consider alternative strategies, including automatic enrollment, employer or governmental nonelective contributions, and mandatory retirement plan contributions. Our findings on incentives, liquidity, and investment choice are also relevant when considering possible models for a reformed Social Security system with individual accounts.

In what follows, we first briefly review prior 401(k) research, and then we describe our methodology and data. Next we report on our analysis of the determinants of employee savings behavior, followed by an assessment of employer matching costs. A final section offers conclusions and implications.

\section{Prior Research}

Previous studies examining participation behavior in 401(k) plans have found some responsiveness of saving rates to employer matching contributions, yet the results are far from uniform. ${ }^{5}$ Various authors report that introducing a match (versus having no match at all) boosts plan participation and plan contribution rates, though the estimated magnitude of this effect ranges widely (from a low of 3 to more than 25 percent). ${ }^{6}$ These results make sense since, all else equal,

\footnotetext{
${ }^{5}$ Yet these prior studies also come to different conclusions mainly because of methodological differences across the works. The studies differ on four important parameters: the unit of analysis (the individual employee or the plan), the data on the employer match (whether detailed information on the match design is available or not), the complexity of retirement plan design (whether a full specification of the entire plan design is present), and the complexity of federal tax rules (as we describe below).

${ }^{6}$ A partial list includes Andrews (1992), Even and Macpherson (1997, 2003), GAO (1997), Papke (1995), Papke and Poterba (1995), and Choi et al. (2004).
} 
offering a match where there was previously no incentive to save should increase the attractiveness of saving in the 401(k) plan. Other studies examine the impact of increasing an existing match, and these report more mixed findings. ${ }^{7}$ Some show saving increases while others indicate negligible or negative effects. ${ }^{8}$ Here the economic intuition is a bit more complex: if an employer raises an existing match by a modest amount, the increase may be too small to have a material effect on saving rates-for example, a small match increase might be insufficient to offset the liquidity and investment costs associated with $401(\mathrm{k})$ plans. Of course it is possible that raising the match rate could have a negative effect, if employees thought in terms of a target lifecycle saving level. ${ }^{9}$

One drawback of many previous studies is that they had data for only one or a small handful of companies, thus limiting the breadth of plan designs to be studied. These company-specific analyses also lack access to integrated and detailed information on matching, liquidity, and investment menu elements of plan design, and sometimes they lack information on whether other retirement plans besides the 401(k) plan were available. Alternatively, researchers using individuallevel survey data (e.g. the Survey of Consumer Finances) have been unable to capture necessary information on plan design, and in particular they lack information about specific match formulas offered. In what follows, we rectify these shortcomings by using a rich dataset containing information on employee and plan characteristics, and we also take proper account of the complex tax rules governing 401(k) plan contributions.

\footnotetext{
${ }^{7}$ See for instance Papke (1995), Clark and Schieber (1998), Munnell et al. (2000), Engelhardt and Kumar (2003), and Huberman et al .(2003).

${ }^{8}$ Studies using individual-level microdata collected from specific companies include Clark and Schieber (1998); Huberman, Iyengar, Jiang ( 2004); and Kusko, Poterba, and Wilcox (1998). Studies using individual-level microdata from nationally representative surveys include Andrews (1992); Basset, Fleming and Rodrigues (1998); VanDerhei and Copeland (2001); Cunningham and Engelhardt (2002); Engelhardt and Kuman (2004); Even and Macpherson (2003); Munnell, Sunden, and Taylor (2000).

${ }^{9}$ For example, an employee with a target saving rate of 9 percent might contribute 6 percent of her own salary when her employer provides a 3 percent match, but if the employer decided to raise the match to 4 percent of pay, she might curtail her own contribution to 5 percent. Pence (2002) posits that workers who participate in 401(k) plans have an inherently greater interest in saving than other workers.
} 


\section{Methodology}

In the US, the employer decision to offer a retirement plan is voluntary, and most privatesector firms with a company-based retirement program offer a 401(k) plan. ${ }^{10}$ While firms have substantial flexibility regarding the design of their retirement plans under the US tax code, the key element in the 401(k) plan that the employee must first contribute some portion of his salary to the plan—known as the employee's "elective deferral" or "salary deferral amount"—-before he is entitled to any matching contribution, if offered. Workers receive substantial tax incentives for saving in these 401(k) plans. Specifically, employee contributions from current wages are taxdeductible up to a legal limit (of $\$ 10,500$ in 2001 , the year of our data set). Further, employer matching contributions up to specified limits are exempt from current taxation; and all investment earnings on the pension account are compound tax-free until withdrawal (typically later in life when tax rates may be lower). ${ }^{11}$

Employees considering whether to join a 401(k) plan must weigh two important constraints. First, by law, 401(k) saving is relatively illiquid, since these assets are generally inaccessible until job change or retirement. Some limited access is available via loans, and participants may typically borrow half their balance with no tax consequences to a maximum of $\$ 50,000 .^{12}$ In addition, some plans permit employees to make after-tax 401(k) contributions, and participants facing certain financial hardships can sometimes request an in-service withdrawal. ${ }^{13}$ Second, employers tend to

\footnotetext{
${ }^{10}$ The retirement program offered by the employer may consist exclusively of a 401(k) plan, or it might combine the 401(k) plan with another type of defined benefit or defined contribution program.

${ }^{11}$ Employers realize no particular tax advantage from offering a 401(k) plan: a firm can deduct employee compensation paid in the form of taxable wages or contributions to a tax-qualified retirement plan. Some analysts suggest that companies may derive a benefit from offering employer stock within a DC plan, but productivity gains from company stock tend to be negligible and may reflect employer and employee myopia about benefits and costs (Benartzi et. al. 2004; Mitchell and Utkus, 2003).

${ }^{12}$ Loans are an optional provision; not all plans offer loans. Participants can typically borrow their own contributions and earnings, plus employer matching contributions and earnings. They may or may not be able to borrow other sources of money, such as an employer profit-sharing contribution to the same plan.

${ }^{13}$ In plans allowing after-tax contributions, participants may choose to contribute earnings after paying taxes. These contributions are immediately available for withdrawal at any time, making them liquid. Earnings are tax-deferred and
} 
limit the 401(k) investment menu: it typically includes a dozen or so funds, which is clearly smaller than all possible retail mutual fund or brokerage account offerings. ${ }^{14}$

Another factor influencing employee contributions is that $401(\mathrm{k})$ plans are subject to a complex set of tax rules that limit plan contributions by highly-paid employees. Section $402(\mathrm{~g})$ of the Internal Revenue Code (IRC) constrains employee contributions to a 401(k) plan: in 2001, the year for which we have data, the cap was $\$ 10,500$ per year. This rule effectively censors plan saving rates for higher earners: for instance, in 2001, a participant earning $\$ 150,000$ had a maximum possible plan saving rate of seven percent $(\$ 10,500$ divided by $\$ 150,000)$, while a participant earning $\$ 1$ million had a maximum possible plan saving rate of about one percent of pay. ${ }^{15}$ Retirement plans are also subject to nondiscrimination testing (NDT) rules for employee pretax elective deferrals. ${ }^{16}$ To implement these rules, a plan sponsor must divide eligible workers into two groups: highly compensated employees (HCEs, earning \$85,000 or more in 2001) and nonhighly compensated employees (NHCEs, or those earning below $\$ 85,000$ in 2001). In the most common situation, the HCEs' plan contribution rate may not exceed that of the NHCEs by more

are subject to restrictions and taxation upon withdrawal. Because of their liquidity, after-tax contributions compete with pre-tax saving, and so any regression of pre-tax saving against after-tax contributions should show a negative coefficient for the after-tax indicator. In a number of plan designs, employees who reach various federal tax limits on pre-tax contributions are able to make additional after-tax contributions, thereby gaining an additional tax benefit, the ability to defer taxes on the earnings on such contributions. According to the Profit Sharing / 401(k) Council of America (2004), nearly half of plans with 5,000 or more participants offer an after-tax feature, compared to less than 5\% of plans with less than 200 participants. In our sample less than $1 \%$ of participants took in-service withdrawals and so we ignore them as a potential source of liquidity for $401(\mathrm{k})$ savings.

${ }^{14}$ At job change or retirement, the participant may roll over plan assets to an Individual Retirement Account (IRA) offering greater investment flexibility.

15 There are two other constraints of note. Under IRS section 415, total employee and employer contributions to any tax-deferred retirement plan cannot exceed $25 \%$ of pay or $\$ 35,000$. For example, a worker earning $\$ 40,000$ in 2001 could only receive total employer and employee contributions of $\$ 10,000$. Also, a $15 \%$ limit for profit-sharing plans applied in 2001, since 401(k) plans are technically organized as profit-sharing plans under US law. As a result, they must generally limit employee and employer contributions to $15 \%$ of the firm's total wage bill. Depending on how many eligible participants actually join the plan and the amounts contributed, plan participants could be subject to a $15 \%$ (or occasionally higher) limit on the sum of employer and employee contributions.

${ }^{16}$ The NDT rules are distinct from the general nondiscrimination rules, which require, among other details, that the "rights, features and benefits" of a plan be allocated equitably across eligible participants. Under this rule, no plan may offer, for example, a higher match to higher-paid employees or to employees based on managerial rank. 
than two percent. ${ }^{17}$ Moreover, when calculating plan saving rates under the NDT rules, the employer can only count pay subject to the Section 401(a) definition of compensation, which caps the maximum level of annual pay considered for retirement plan purposes $(\$ 170,000$ in 2001$)$. Consequently an employee earning \$1 million and contributing \$10,500 would have an actual plan contribution rate of just over one percent ( $\$ 10,500$ divided by $\$ 1$ million), but his plan saving rate for federal tax purposes would be 6.18 percent $(\$ 10,500$ divided by $\$ 170,000)$.

The practical effect of these rules is that individual employees' potential plan saving rates are constrained by what their co-workers do. As the number of HCEs contributing the maximum allowable level rose, saving rates for the HCE group would converge toward 6.18 percent for federal tax purposes (in 2001). Accordingly, such an employer would need to encourage the NHCEs to save at least 4.18 percent of earnings (two percent less than the HCE threshold of 6.18 percent) in order to comply with nondiscrimination testing. Further, some employers would need to boost NHCE saving rates above 4.18 percent, as not all HCEs contribute the maximum $\$ 10,500$ per year. In the end, if many NHCEs failed to join the plan (i.e., their plan deferral rate was zero percent), it would become difficult to satisfy this criterion, and the plan is said to "fail" testing. Employers in that case will typically limit contributions by the highly paid (to an amount below $\$ 10,500)$ in comply with the rules. ${ }^{18}$

\footnotetext{
${ }^{17}$ In the most common case of the Actual Deferral Percentage or ADP test, if the saving rates of the NHCEs fall between $2 \%$ and $8 \%$, the HCE saving rate cannot be more than $2 \%$ higher than the NHCE rate. There are different rules when NHCE saving rates fall below $2 \%$ or above $8 \%$.

${ }^{18}$ When a plan fails NDT testing, the plan can either refund HCEs' contributions above the permissible amount, which is a laborious and time-consuming process for the employer and may require the employee to file a revised tax return, or alternatively the employer may simply limit HCE contributions to some lower rate to avoid failing the test in the first place. For example, an employer could restrict HCEs to no more than a $6 \%$ contribution rate to meet the nondiscrimination rules, in which case a HCE earning $\$ 100,000$ would be allowed to contribute only $6 \%$, rather than the statutory $10.5 \%$ of salary noted above. In practice HCEs are often capped at a flat rate (such as $6 \%$ ) when a plan fails nondiscrimination testing, though the sponsor may also impose a dollar limit. HCEs subject to a cap in the 401(k) plan are sometimes eligible for executive compensation or non-qualified plans instead. Another option for capping HCEs is to subject those in executive plans to a smaller 401(k) limit, while allowing lower-paid HCEs not eligible for the executive plan to save at a higher rate.
} 
The relevant details must be captured in any model of 401(k) participation and savings patterns. A first model, summarized in Equation (1) below, does so by linking employee saving patterns to several sets of explanatory variables: (1) a vector of plan design features $\left(P D_{j}\right.$, ), including the design of the match, features of the investment menu, and pre-retirement money access methods such as loans; (2) a vector of worker characteristics $\left(\mathrm{EE}_{i}\right)$, which captures employees' taste for saving independent of plan design; and (3) a vector of employer-level variables $\left(E R_{j}\right)$ including plan size, the industry of the plan sponsor, and the presence of other types of retirement plans:

$$
\text { EEBehavior }=\beta_{0}+\beta_{1} \cdot P D_{j}+\beta_{2} E R_{j}+\beta_{3} E E_{i}+\varepsilon_{1}
$$

This formulation allows us to distinguish the impact of features of the 401(k) plan design, versus the saving patterns attributable to employee characteristics and features of the sponsoring firm. To capture the impact of the key tax limitations, we evaluate plan participation and plan contribution rates for NHCEs and HCEs separately.

A second model examines employer expenditures for 401(k) matching contributions, taking into account the fact that the actual cost paid by the employer (as opposed to the promised match) depend on actual employee saving at each firm. ${ }^{19}$ The dependent variable of interest in Equation (2) is therefore the employer's actual match cost as a percentage of pay (ERContrOverComp). We examine how this actual cost varies according to plan design elements $\left(P D_{j}\right.$, $)$, worker characteristics $\left(\mathrm{EE}_{i}\right)$, and employer-side variables $\left(E R_{j}\right)$ :

$$
\text { ERContrOverComp }=\lambda_{0}+\lambda_{1} \cdot P D_{j}+\lambda_{2} E R_{j}+\lambda_{3} \cdot E E_{i}+\varepsilon_{2}
$$

\footnotetext{
${ }^{19}$ Here we consider only costs of matching contribution. We acknowledge but cannot measure other administrative costs including legal and compliance costs, recordkeeping fees, and expenditures on employee communications.
} 


\section{Descriptive Statistics}

Our analysis of 401(k) plan design draws on a unique and rich set of administrative records for 507401 (k) plans, obtained from Vanguard for the 2001 plan year. ${ }^{20}$ Each plan record includes information on important design features including the employer's match formula, features of the plan's investment menu, the presence of other retirement plans (such as a defined benefit or other DC plan), and indicators of participant access to plan accumulations prior to retirement. We also obtained records on nearly 740,000 employees in the firms offering these plans; these data included workers' age, sex, job tenure, annual salary, plan participation, plan contribution amounts, and asset and contribution allocation information. ${ }^{21}$

The mean employer in our sample (see Table 1) is a mid-sized firm with about 1,500 employees; some 82 percent offered a match for employee 401(k) plan contributions. ${ }^{22,23}$ Matching formulas range from zero (18 percent of plans) to very generous matches of more than dollar-fordollar on at least six percent of pay (for two percent of plans). Panel A shows that the median match by firms offering a match is 50 cents per dollar on the first six percent of employee contributions, confirming Papke's earlier result (1995). But we also find that employer match patterns are extremely nonlinear: the average firm matches an average of 55 cents per dollar the

\footnotetext{
${ }^{20}$ The identity of individual firms and plan participants is masked. Union plans are excluded from our sample of 507 plans, since there the match is collectively bargained rather than determined solely by the employer.

${ }^{21}$ The datafile does not include measures of employee educational attainment or workplace financial education programs; however, all employees received plan enrollment material and a quarterly plan newsletter, and all had access to online educational materials. Since we lack data on vesting schedules for employer contributions, indicating participants' ability to take employer contributions with them when they change jobs, we also investigated tenure patterns (in analysis available on request) and results are similar to those reported below.

${ }_{22}$ According to the US Department of Labor, $84 \%$ of full-time private industry employees in the US in 2000 were in saving and thrift plans with a "determinable" match rate (DOL, 2004: 69).

${ }^{23}$ Even in the one of five plans that did not provide a "match," some proportion does have employer contributions elsewhere in the retirement benefit design — whether to a defined benefit plan, a companion money purchase plan, a companion profit-sharing or employee stock ownership (ESOP) plan, or a profit-sharing or ESOP contribution to the 401(k) plan itself. The other DC plan contributions are not considered "matching" contributions because they are made to all eligible employees, not just 401(k) participants; they may be discretionary; and they are not made contemporaneously with employee 401(k) contributions. Sometimes, however, these other contributions are described as a "match" by employers.
} 
employee contributes on his first three percent of salary; 37 cents per dollar on his next three percent of pay; and only five cents per dollar for his next two percent of pay. There is also substantial variation in the so-called "match cap," which is the amount the employee must deposit to obtain the largest possible employer subsidy: the mean is around five percent of pay, while the median is six percent.

\section{Table 1 here}

The most common formula provided is a single-tier match formula, such as $\$ 0.50$ on the dollar to six percent of pay. Another 11 percent of the plans offers a multi-tier formula, where the employer offers a higher incentive on the first level of pay (such as 100 percent on the first two percent of employee contributions) and a lower incentive on subsequent levels of pay (such as 50 percent on the next two percent). The nonlinearity of $401(\mathrm{k})$ matching contributions is captured in Figure 1, which summarizes the match rate and tier for the single-tier formulas in our data file.

\section{Figure 1 here}

It is useful to divide these highly nonlinear 401(k) match formulas into an incentive_element, reflecting how much the employee is rewarded per dollar contributed, versus a liquidity element, indicating how much compensation the employee must "tie up" in the 401(k) plan in order to receive the entire employer incentive payment. Accordingly we define a variable Match $f 3$ that indicates the value of the employer's matching contribution on the first 3 percent of pay contributed by the employee (i.e., from 0 to 3 percent); Match_n 3 captures the rate on the next 3 percent of pay (i.e., from 4 to 6 percent of pay); and Match_n2 reflects the value of the match on an additional 2 percent of pay (i.e., over 6 and up to 8 percent of pay). Another variable, EEReqContr4 MaxMatch, captures how much the employee must contribute to receive the maximum subsidy from the employer. For example, in a tiered formula that paid dollar-for-dollar up to two percent of pay, and 50 cents per dollar from 2-4 percent of pay, the maximum required employee contribution is four 
percent. For the single-tier match plans, Figure 2 shows the maximum amount employers promise in the form of matching contribution. About one-third of all plans promises to provide less than three percent of pay; about one-third offers exactly three percent; and about one-third, more than three percent. $^{24}$

Figure 2 here

Looking across the 507 plans in the sample, we note that they offer an average of 12.6 investment choices in their plan menus; 19 percent offer employer stock as an investment choice; and two-thirds of the investment options are equity funds. In terms of pension liquidity, the overwhelming majority of the plans (85 percent) offer a loan feature, while one quarter permits after-tax contributions. As noted earlier, the sponsoring firm may also offer other retirement plans along with the 401(k) plan. Table 2 indicates that the 401(k) plan designs fall into three broad categories: firms offering 401(k) plans alone (some 39 percent of plans); firms offering 401(k) plans accompanied by another DC plan such as a money purchase, profit-sharing, or ESOP plan (28 percent); and firms providing 401(k) plans paired with some form of DB plan (34 percent of plans). ${ }^{25}$ (This variation in plan design suggests that it is too simplistic to describe the historic trend in private pension provision as a shift from DB plans to $401(\mathrm{k})$ plans.)

\section{Table 2 here}

A summary of employee characteristics for the more than 740,000 workers in our full sample appears in Table 3. Across plans, the average participant in the average plan is male, is nearly 43 years of age, earns $\$ 63,900$ a year, and has spent almost nine years on the job. The

\footnotetext{
${ }^{24}$ At the employee level, since more participants are in large plans, nearly four in ten participants are provided with a match equivalent of $3 \%$ of pay. But this $3 \%$ promise can manifest itself in quite different ways in terms of required employee contribution: as a $\$ 0.50$ on the dollar match on a $6 \%$ employee contribution, as a $\$ 1$ for dollar match on a $3 \%$ employee contribution, or, less frequently, something in-between.

${ }^{25}$ In the case of DC plans, a 401(k) participant may receive an employer contribution to a companion money purchase plan, profit-sharing plan, or Employee Stock Ownership Plan (ESOP). The profit-sharing or ESOP contribution may be integrated within the $401(\mathrm{k})$ plan itself, or it may be in a standalone plan.
} 
average plan participation rate is 77 percent,${ }^{26}$ with contribution rates for those saving in the plan amounting to 6.8 percent of pay; the average $401(\mathrm{k})$ account balance is $\$ 54,400 .{ }^{27}$ An important finding is that, although the typical employer-promised match is three percent of pay, the cost of this match to the median employer is actually only two-thirds this value, or 1.9 percent of pay. In other words, workers forfeit much of the match because they fail to participate in their plans (63 percent of 1.1 percent, or 0.7 percent of pay), or because they fail to save at a rate needed to earn the full employer match (37 percent of 1.1 percent, or 0.4 percent of pay) ${ }^{28}$ In terms of investment decisions, employees contribute 74 percent of their new money to equity funds, and 14 percent to company stock. The average participant avails himself of only 3.5 of the investment choices in his pension portfolio, versus the 12.6 funds offered. About one-quarter of participants in the average plan is registered to use the Internet to manage their accounts in 2001; 15 percent have a loan outstanding.

Table 3 here

One invaluable attribute of the plan-level data is that we can compute with some accuracy what fraction of the covered workers falls into the highly compensated employee group under federal nondiscrimination testing rules. In the average plan, almost one-fifth (19 percent) of participants are highly compensated employees who differ in important ways from their NHCE counterparts. Table 3 shows that HCEs have substantially higher account balances, are older, are longer-tenured, and predominantly male. As expected, HCEs participate at much higher rates in the 401(k) plans than do NHCEs (91 vs 74 percent). However, HCEs contribute at roughly the same

\footnotetext{
${ }^{26}$ This is the participation rate calculated at the plan level. Across the universe of employees, the participation rate is $66 \%$. The reason for this difference is that participants are skewed to the largest plans, and larger plans tend to have lower participation rates, often because they offer another retirement plan besides the 401(k) plan.

${ }^{27}$ The plan-weighted average participation rate is $77 \%$--i.e., the average of participation rates calculated at the plan level is significantly higher. This is because large plans have more employees, and they also have much lower 401(k) participation rates (often because they offer other retirement plan benefits).

${ }^{28}$ This accords with recent findings of Choi et al. (2004).
} 
rate of pay as NHCEs (6.8 vs 6.9 percent), reflecting the impact of federal contribution limits. In the dataset, HCEs control about 41 percent of the 401(k) assets in the average plan though they represent 19 percent of participants. In terms of investments, HCEs contribute slightly more to equities (79 vs 73 percent); they use the web more frequently to manage their accounts (42 vs 23 percent); and they are somewhat less likely to take a loan (11 vs 15 percent).

Table 3 also indicates how many employees are subject to other pension tax limits. More than one-tenth (11 percent) of participants in the average plan were at the $402(\mathrm{~g})$ limit of $\$ 10,500$ for pre-tax 401(k) plan contributions (in 2001). But this average conceals important cross-group differences: 41 percent of the highly compensated employees are at the limit, while only three percent of the nonhighly compensated are thus constrained. We are also able to estimate that 10 percent of plans are subject to employer-imposed NDT caps (these "caps" influence only 1.2 percent of HCEs in our entire sample). Finally, we estimate that about 6 percent of participants in the average plan are subject to either the Section 415 limit (25 percent of pay or $\$ 35,000)$ limit or any other plan-specific limit.

\section{Multivariate Empirical Analysis}

Next we report results of the multivariate analyses of 401(k) saving behavior and employer match costs. Table 4 summarizes results for employee saving patterns, where a key finding pertains to match design. Specifically, a larger match on the first three percent of pay and a higher match threshold has a significantly positive impact on the fraction of NHCEs participating in the plan (col. 1). There is some support for this in previous studies. ${ }^{29}$ Yet the magnitude is not large: each $\$ 0.10$ increase in the match rate raises the NHCE participation rate by 0.8 percent points (i.e., from 77

\footnotetext{
${ }^{29}$ Only Papke (1995) and Papke and Poterba (1995) use firm-level analysis and they detect a positive association between plan participation and match generosity. However they do not exploit the detailed nonlinearity of the match rate as do we. Papke (1995) uses aggregate Form 5500 data, so she must infer rough match rates from actual plan contributions of employers and employees. Papke and Poterba (1995) have a small sample of plans (43). Both studies have access to only a few independent variables including the match rate, plan size, and the presence of another plan.
} 
percent to 77.8 percent). Further, among the NHCEs, participation incentives dwindle between 3 and 6 percent of pay, and it turns negative on matches above six percent of pay. These results suggest that the match incentives are designed mainly to satisfy nondiscrimination testing requirements. As noted above, HCEs save up to federal tax rule limits, converging on 6.18 percent (as the number of HCEs earning \$170,000 and saving \$10,500 increases), and so required NHCE contributions would be in excess of 4.18 percent to comply with federal nondiscrimination testing rules.

\section{Table 4 here}

Another finding relates to the impact of investment constraints on plan participation. Offering a larger investment menu encourages more NHCEs to participate but at a declining rate. Indeed participation appears to peak when the employer offers 30 funds, falling after that $[-1.177 /(-$ $0.02 * 2)=30$ ]. It is interesting that offering more funds has a powerful positive effect on the fraction of HCEs saving at the maximum allowable limit. This controls on the mix of funds offered, which also has an interesting independent effect. Specifically, if the investment menu includes a larger share of equity funds, this is associated with lower NHCE participation, and the effect is relatively powerful: if the proportion of stock funds rises by 10 percent, the participation rate of NHCEs falls by 1.62 percentage points. In effect, NCHE participants exhibit not only "choice overload" as suggested by Jiang and Iyengar (forthcoming), but also "equity fund overload."

Factors influencing the level of plan contributions are also interesting. As the match generosity rises (in particular, on the first three percent of pay), NCHE contribution rates fall, as if employer matching substituted for employee contributions. ${ }^{30}$ Plan contribution rates are also very

\footnotetext{
${ }^{30}$ Previous studies using firm-based data offer mixed results on this point. Thus Papke (1995) reports that introducing a match rased employee contributions, but the marginal change in employee contributions was negative at higher match rates. Papke and Poterba (1995) found that introducing a match increased employee contributions but they reported no effect of higher match rates. Research using individual-level data also provides mixed conclusions: Clark and Schieber
} 
sensitive to the relaxation of liquidity constraints: the presence of a loan, while not associated with plan participation, does raise plan contribution rates by 10 percent (consistent with Munnell et al., 2000, and Holden and VanDerhei, 2001). It is also interesting that allowing employees to make after-tax contributions reduces pre-tax contributions. ${ }^{31}$

These marginal effects are summarized in Table 5 and Figure 3, where we display combinations of NHCE participation and contribution rates as a function of matching contributions (holding demographics and firm characteristics at their sample means). The most striking finding is the small variation in predicted plan participation due to changes in the match design (Table 5 Panel B, and Figure 3 Panel A). The empirical model implies that roughly 60 percent of NHCEs at the typical firm would join their 401(k) plan regardless of the presence of a match. Plan participation would be estimated to rise over a narrow range, by 5-15 percentage points, responding to a range of match offerings, from a modest ( $\$ 0.25$ per dollar on the first three percent of pay) to a very generous match ( $\$ 1.00$ per dollar up to six percent of pay). At the modal promised employer match (\$0.50 per dollar on six percent), nearly 30 percent of the NHECs fails to participate in the employer's plan; even with a generous match, more than 20 percent still fails to join. In terms of plan contributions, we find that more generous matches are associated with small declines in NHCE contribution rates (Table 5 Panel C, and Figure 3 Panel B). By contrast, the positive effect of a loan on contribution rates is much more pronounced.

\section{Table 5 and Figure 3 here}

Another way to assess the plan participation results is to estimate the implicit return that employees forfeit, when they fail to take advantage of the employer match provided in the $401(\mathrm{k})$

(1998), Cunningham and Engelhardt (2002), and Huberman et al (2004) suggest that higher match rates increase employee contribution rates; Engelhardt and Kumar (2004) and Kusko et al. (1998) report a negative effect; and Munnell et al. (2000) finds no impact.

${ }^{31}$ In terms of employee traits, we find that mean compensation, tenure, and the fraction female are all significant factors in predicting plan participation and contribution rates. Age insignificant as there is little cross-plan age variation. 
plan. For example, an employee who contributed $\$ 1$ to a $401(\mathrm{k})$ and earned a 4 percent real return over 30 years, could anticipate $\$ 3.24$ in retirement assets from this contribution. If she also received $\$ 1$ in matching employer contributions for this $\$ 1$, her balance would instead to $\$ 6.48$ at retirement. In other words, had she not received the match, she would have had to earn a real return of 6.4 percent on her contributions-2.4 percent per annum real above the 4 percent baseline-to attain the equivalent amount of retirement saving.

More generally, the implicit return on the employer match over $n$ years is that rate $r$ that equates the present value of employee contributions, to the present value of the employee's account balance at retirement including both employee and employer contributions. ${ }^{32}$ Figure 4 summarizes the results. For companies where no employer match is offered, the expected return on the employee's contributions is the assumed to be the real rate of return on 401(k) investments, four percent. Alternative match designs ranging from $\$ 0.25$ on the dollar on three percent of pay, up to $\$ 1.00$ per dollar on six percent of pay, the implicit rate of return on employee contributions ranges from 4.7 percent to 9.5 percent. In effect, participants who do join the plan solely due to the match must expect require a premium greater that the four percent benchmark return, ranging from 0.7 to 5.5 percent depending on the plan. ${ }^{33}$

Figure 4

Overall, then, in a typical 401(k) plan, only 10 percent of non-highly compensated workers are induced to save in the plan, and 30 percent fail to join the plan at all, based on company-offered incentives that grant a substantial 1-5 percent premium over expected market returns. Such

\footnotetext{
${ }^{32}$ In practice, we assume that the latter grows at a given real market rate of return, rm, on 401(k) investments; the calculations assume a value for rm of 4 percent; that the employer is offering various match designs to our average nonhighly compensated workforce (mean earnings of $\$ 42,000,6$ percent contribution rate); and that savings occur for 20 years (from the mean workforce age of 42 to age 62 ).

${ }^{33} \mathrm{We}$ acknowledge that these calculations overlook the risk premia associated with future contribution patterns, as well as the uncertainty of job tenure with given employers. Yet despite these return premia, it is remarkable that so many non-participants still judge 401(k) saving to be "not worth" the costs.
} 
indifference to retirement saving cannot be explained by liquidity constraints, inasmuch as relaxing liquidity constraints via a loan feature has no effect on participation rates among the non-highly paid and increases contribution rates for participants by only 10 percent. Nor are investment restrictions a strong explanation, since expanding investment choice has a two-edged effect, increasing participation generally but also inducing some degree of choice overload. Thus we are left with a strikingly strong level of savings aversion, apparently quite resistant to substantial economic incentives.

Evidence regarding the cost of employer matching contributions appears in Table 6, where we see that actual employer expenditures as a percent of the employer's total wage bill are linked to match design, not surprisingly. More generous match rates on the first three and the next three percent of compensation (Match_f3 and Match_n2) are associated with higher employer match costs. Offering a loan has a small effect: loans raise employee contributions at the margin, and so they imply that more plan participants receive a larger matching contribution. Marginal effects, summarized in Table 7 (Panel A), show that small changes in match rates can raise costs by 8-12 percent. Adding loans raise employer match outlays by 15 percent.

\section{Table 6 and 7 here}

As noted earlier, the typical plan has a promised match rate of three percent but this costs the employer only two percent of pay, due to the failure of employees to maximize plan saving. In effect, employees forfeit about one-third of promised retirement compensation. It is worth noting that companies with higher-paid workforces are also those which generally pay higher matching contributions (c.f. Mitchell, Utkus and Yang, 2005), and higher-paid employees are also those who tend to save and participate at higher levels. The overall result, then, is that higher-paid workers capture a larger retirement subsidy than lower-paid employees. 
Next we summarize estimated employer costs across several match designs, controlling for the tendency of better-paid workers to receive and take advantage of better match offers. Results appear in Table 7 (Panel B) and Figure 5. Forfeited compensation ranges from 66 percent of the smallest promised match ( $\$ 0.25$ on the dollar on 3 percent of pay) down to 42 percent of pay for a very generous match ( $\$ 1$ per dollar on 6 percent of pay). Controlling for cross-plan compositional differences, the average amount of forfeited pay is 50 percent of the match - in essence, the pure cost of forfeited retirement compensation. Of the half of retirement compensation that employers do end up paying, two-thirds is attributable directly to the offered match, while another third is attributable to the higher employee saving triggered by the loan feature.

Figure 5 here

\section{Implications and Conclusions}

Our unique new data set on more than 500 plans permits a detailed examination of the complex set of incentives embedded in 401(k) pensions. The results show that matching contributions have only a minimal influence on workers' decision to join the 401(k) plan, inducing only 10 percent of eligible workers in the typical plan to participate. Despite matches providing substantial implicit real return premiums on employee contributions, 20-30 percent of eligible workers still fail to join their employers' plans. After adjusting for variations in employee demographics at the plan level, we conclude that workers effectively forfeit half of their promised retirement compensation due to not maximizing the match. These results highlight how daunting it is to incentivize retirement saving using matching efforts. We also show that the liquidity and investment constraints inherent in these plans have only modest influences on plan participation and saving rates.

Our findings are suggestive for employers and policymakers. They indicate, first, that taxmotivated matching contributions in $401(\mathrm{k})$ plans are a crude way to build broad-based engagement 
in retirement saving plans. Those who seek to enhance retirement security among low-income and low-tenured populations might consider alternatives to matching contributions in $401(\mathrm{k})$ plans. Options include automatic enrollment (c.f. Madrian and Shea, 2001), non-elective contributions by employers or the government, and mandatory retirement plan contributions. Reframing enrollment as a negative election encourages 401(k) saving regardless of the firm-specific match incentive, and it also induces retirement saving regardless of specific predilections. It is also worth nothing that the same objective can be achieved if employers simply made nonelective contributions for all workers, thus substituting corporate retirement saving preferences in place of employees' weak tastes for saving. Mandatory retirement system rules in Singapore and Australia create uniform retirement saving patterns independent of firm-, employee- or plan-specific characteristics.

Second, plan sponsors should be aware that investment menu design and loan features have mixed effects on employee saving behavior. Menu design appears to have its greatest influence on plan participation, but it still represents a tension between two competing forces: more choice expands participation, but too many complex choices lead to "choice overload." Striking a balance between choice and complexity remains important for corporate pension sponsors, public sector employers, and Social Security designers of any individual investment accounts program. We also confirm that liquidity is valuable in raising pension contribution rates. But the fact that relaxing investment and liquidity constraints in 401(k) savings has such minor effects underscores our broader finding on saving incentives. The challenges of encouraging additional 401(k) saving do not appear to be mainly associated with investment or liquidity constraints embedded in such programs. Rather, they are more closely linked to workers' weak tastes for saving and their inability to fully exploit complex 401(k) plans, making them relatively immune to saving incentives offered by their employers. 
Table 1. Employer 401(k) Plan Design: Descriptive Statistics (Plan Level)

Panel A. Employer Match Rates and Other Plan Design Features

\begin{tabular}{|c|c|c|c|}
\hline & Variable Name & Mean & Median \\
\hline Number of employees covered & Plan_size & 1,460 & 283 \\
\hline Employer plan provides match for employee contributions & Positive_match & $82 \%$ & \\
\hline Match rate on first $3 \%$ of compensation $(0-3 \%)$ & Match_f3 & $\$ 0.55$ on $\$ 1$ & $\$ 0.50$ on $\$ 1$ \\
\hline Match rate on next $3 \%$ of compensation (3-6\%) & Match_n3 & $\$ 0.37$ on $\$ 1$ & $\$ 0.33$ on $\$ 1$ \\
\hline Match rate on next $2 \%$ of compensation $(6-8 \%)$ & Match_n2 & $\$ 0.05$ on $\$ 1$ & $\$ 0.00$ on $\$ 1$ \\
\hline $\begin{array}{l}\text { Match rates conditional on a match being offered: } \\
\text { Match rate on first } 3 \% \text { of compensation (0-3\%) } \\
\text { Match rate on next } 3 \% \text { of compensation (3-6\%) } \\
\text { Match rate on next } 2 \% \text { of compensation (6-8\%) }\end{array}$ & & $\begin{array}{l}\$ 0.67 \text { on } \$ 1 \\
\$ 0.49 \text { on } \$ 1 \\
\$ 0.44 \text { on } \$ 1\end{array}$ & $\begin{array}{l}\$ 0.50 \text { on } \$ 1 \\
\$ 0.50 \text { on } \$ 1 \\
\$ 0.50 \text { on } \$ 1\end{array}$ \\
\hline Promised employer match as $\%$ of pay & MaxCostErMatch & $3.00 \%$ & $3.00 \%$ \\
\hline $\begin{array}{l}\text { Employee contribution required for maximum employer plan } \\
\text { match (the "match cap") }\end{array}$ & Contr4MaxMatch & $4.90 \%$ & $6.00 \%$ \\
\hline Number of funds offered in plan & NFundsOffered & 12.6 & 11 \\
\hline Fraction of funds offered that are equity funds & Fund_stock & $65 \%$ & $67 \%$ \\
\hline Employer stock offered in plan & ER_stock & $19 \%$ & \\
\hline Employer plan permits after-tax contributions & After_tax & $24 \%$ & \\
\hline Employer plan offers loan & loan & $85 \%$ & \\
\hline
\end{tabular}

\section{Panel B. Characteristics of Employer Match Formulas}

\begin{tabular}{|c|c|c|c|c|c|}
\hline Type of formula & Example & $\begin{array}{l}\text { No. of } \\
\text { plans }\end{array}$ & $\%$ of plans & $\begin{array}{c}\text { No. of } \\
\text { employees }\end{array}$ & $\begin{array}{c}\% \text { of } \\
\text { employees }\end{array}$ \\
\hline Single match & $50 \%$ on first $6 \%$ of pay & 360 & $71 \%$ & 535,078 & $72 \%$ \\
\hline Multi-tier formula & $\begin{array}{c}100 \% \text { on first } 2 \% \text { of pay; } \\
50 \% \text { on next } 2 \%\end{array}$ & 56 & $11 \%$ & 104,044 & $14 \%$ \\
\hline No match & - & 91 & $18 \%$ & 100,853 & $14 \%$ \\
\hline TOTAL & & 507 & $100 \%$ & 746,690 & $100 \%$ \\
\hline
\end{tabular}

Note: Data derived from 507 plans; see text. 
Table 2: Employer Retirement Plan Offerings

\begin{tabular}{|c|r|r|r|r|r|}
\hline Type of Retirement Plan Offered & \multicolumn{1}{|c|}{$\begin{array}{c}\text { No. of } \\
\text { plans }\end{array}$} & \multicolumn{1}{c|}{$\begin{array}{c}\text { \% of } \\
\text { plans }\end{array}$} & $\begin{array}{c}\text { No. of } \\
\text { employees }\end{array}$ & \multicolumn{1}{c|}{$\begin{array}{c}\text { \% } \\
\text { employees }\end{array}$} & $\begin{array}{c}\text { Average } \\
\text { plan size }\end{array}$ \\
\hline 401(k) only & 196 & $39 \%$ & 187,004 & $25 \%$ & 954 \\
\hline $401(\mathrm{k})$ plus DC & 140 & $28 \%$ & 82,325 & $11 \%$ & 588 \\
\hline $401(\mathrm{k})$ plus DB & 102 & $20 \%$ & 177,999 & $24 \%$ & 1,745 \\
\hline 401(k) plus DB and DC & $\underline{69}$ & $\underline{14 \%}$ & $\underline{292,647}$ & $\underline{40 \%}$ & 4,241 \\
\hline & & & & & \\
\hline TOTAL & 507 & $100 \%$ & 739,975 & $100 \%$ & 1,460 \\
\hline
\end{tabular}

Note: Data derived from 507 plans; see text. 
Table 3: Employee Demographics and Plan Behavior: Descriptive Statistics (Plan Level)

\begin{tabular}{|c|c|c|c|}
\hline & Variable Name & $\begin{array}{c}\text { Plan Mean } \\
\text { (HCE, NHCE)* }\end{array}$ & $\begin{array}{c}\text { Plan Median } \\
\text { (HCE, NHCE)* }\end{array}$ \\
\hline \multicolumn{4}{|l|}{ PANEL A: EMPLOYEE CHARACTERISTICS } \\
\hline Age & Mean_age & $\begin{array}{r}42.7 \text { years } \\
(47.4,41.9) \\
\end{array}$ & $\begin{array}{r}42.9 \text { years } \\
(42.2,41.9) \\
\end{array}$ \\
\hline Income $(\$ 000)$ & Mean_comp & $\begin{array}{c}\$ 63.9 \\
(\$ 157.4, \$ 42.0) \\
\end{array}$ & $\begin{array}{c}\$ 55.5 \\
(\$ 136.4, \$ 42.3) \\
\end{array}$ \\
\hline Job tenure & Mean_tenure & $\begin{array}{r}8.7 \text { years } \\
(12.3,8.2) \\
\end{array}$ & $\begin{array}{r}8.3 \text { years } \\
(11.5,7.6) \\
\end{array}$ \\
\hline Sex (\% female) & Female_pct & $\begin{array}{c}36 \% \\
(15 \%, 42 \%)\end{array}$ & $\begin{array}{c}33 \% \\
(11 \%, 39 \%)\end{array}$ \\
\hline \multicolumn{4}{|l|}{ PANEL B: PLAN BEHAVIOR } \\
\hline$\%$ Participating & ParticipationRate & $\begin{array}{c}77 \% \\
(91 \%, 74 \%) \\
\end{array}$ & $\begin{array}{c}79 \% \\
(94 \%, 76 \%)\end{array}$ \\
\hline $\begin{array}{l}\text { Contribution as \% of pay (for those } \\
\text { participating) }\end{array}$ & ContributionRate & $\begin{array}{c}6.8 \% \\
(6.8 \%, 6.9 \%) \\
\end{array}$ & $\begin{array}{c}6.8 \% \\
(6.6 \%, 7.0 \%) \\
\end{array}$ \\
\hline Employer's contribution (\% of pay) & ErContrOverComp & $\begin{array}{c}1.8 \% \\
(1.9 \%, 1.9 \%)\end{array}$ & $\begin{array}{c}1.9 \% \\
(1.8 \%, 1.8 \%)\end{array}$ \\
\hline Account balance $(\$ 000)$ & & $\begin{array}{c}\$ 54.4 \\
(\$ 153.8, \$ 35.5) \\
\end{array}$ & $\begin{array}{c}\$ 46.7 \\
(\$ 127.8, \$ 31.6) \\
\end{array}$ \\
\hline$\%$ Contribution to equities & Avg_Equity_pct & $\begin{array}{c}74 \% \\
(79 \%, 73 \%)\end{array}$ & $\begin{array}{c}75 \% \\
(80 \%, 74 \%)\end{array}$ \\
\hline$\%$ Contribution to company stock & Avg_ComStk_pct & $\begin{array}{c}14 \% \\
(14 \%, 14 \%)\end{array}$ & $\begin{array}{c}7 \% \\
(8 \%, 7 \%) \\
\end{array}$ \\
\hline Number of funds used & Avg_NumFundsUse & $\begin{array}{c}3.5 \\
(3.8,3.4)\end{array}$ & $\begin{array}{c}3.4 \\
(3.7,3.3)\end{array}$ \\
\hline$\%$ Web usage to manage $401(\mathrm{k})$ account & Web_Use Rate & $\begin{array}{c}26 \% \\
(42 \%, 23 \%) \\
\end{array}$ & $\begin{array}{c}23 \% \\
(41 \%, 21 \%) \\
\end{array}$ \\
\hline$\%$ Taking a loan & Loan_takerate & $\begin{array}{c}15 \% \\
(11 \%, 15 \%) \\
\end{array}$ & $\begin{array}{c}13 \% \\
(9 \%, 14 \%) \\
\end{array}$ \\
\hline \multicolumn{4}{|l|}{ PANEL C: IMPACT OF TAX LIMITS } \\
\hline$\%$ Employees HCEs & & $17 \%$ & \\
\hline$\%$ Participants HCEs & HCE_pct & $19 \%$ & \\
\hline$\%$ Plan assets owned by HCEs & & $41 \%$ & \\
\hline$\%$ Plans that cap HCEs & & $10 \%$ & \\
\hline $\begin{array}{l}\% \text { Participants at plan contribution limit }< \\
\$ 10.5 \mathrm{~K}\end{array}$ & Avg_limit_plan_pct & $\begin{array}{c}6.1 \% \\
(1.3 \%, 7.4 \%) \\
\end{array}$ & \\
\hline$\%$ of Participants at $\$ 10.5 \mathrm{k}$ limit & $\begin{array}{l}\% \text { of participants at } \\
\$ 10.5 \mathrm{k} \text { limit }\end{array}$ & $\begin{array}{c}11 \% \\
(41 \%, 2.5 \%)\end{array}$ & $\begin{array}{c}7 \% \\
(43 \%, 1.2 \%)\end{array}$ \\
\hline
\end{tabular}

Note: Statistics cover 489,526 participants and 250,449 eligible non-participants in 507 plans.

* In 2001, HCEs are those earning at least $\$ 85,000$; NHCEs earned below $\$ 85,000$. 
Table 4. Plan-Level Participation and Contribution Responses to 401(k) Design Features

\begin{tabular}{|c|c|c|c|c|}
\hline & \multicolumn{2}{|c|}{ NHCEs } & \multicolumn{2}{|c|}{ HCES } \\
\hline & $\frac{\text { Participation }}{\underline{\text { Rate }}}$ & $\begin{array}{c}\text { Participant } \\
\text { Contribution Rate } \\
\end{array}$ & $\frac{\text { Participation }}{\text { Rate }}$ & $\frac{\% \text { of Participants }}{\text { at } \$ 10.5 \mathrm{k} \text { limit }}$ \\
\hline \multicolumn{5}{|c|}{$\overline{P L A N ~ C H A R A C T E R I S T I C S}$} \\
\hline Match_f3 & $\begin{array}{c}0.098 \\
{[0.022]^{* *}} \\
\end{array}$ & $\begin{array}{c}-0.004 \\
{[0.002]^{*}}\end{array}$ & $\begin{array}{c}0.049 \\
{[0.016]^{* *}} \\
\end{array}$ & $\begin{array}{l}-0.005 \\
{[0.039]} \\
\end{array}$ \\
\hline Match_n3 & $\begin{array}{l}-0.0001 \\
{[0.031]} \\
\end{array}$ & $\begin{array}{c}0.001 \\
{[0.002]} \\
\end{array}$ & $\begin{array}{c}0.038 \\
{[0.022]}\end{array}$ & $\begin{array}{c}-0.119 \\
{[0.061]}\end{array}$ \\
\hline Match_n2 & $\begin{array}{c}-0.092 \\
{[0.040]^{*}}\end{array}$ & $\begin{array}{c}0.002 \\
{[0.003]}\end{array}$ & $\begin{array}{c}-0.031 \\
{[0.031]}\end{array}$ & $\begin{array}{c}-0.053 \\
{[0.072]}\end{array}$ \\
\hline Contr4MaxMatch & $\begin{array}{c}0.844 \\
{[0.308]^{* *}}\end{array}$ & $\begin{array}{c}0.051 \\
{[0.028]} \\
\end{array}$ & $\begin{array}{c}0.281 \\
{[0.269]} \\
\end{array}$ & $\begin{array}{c}1.425 \\
{[0.493]^{* *}}\end{array}$ \\
\hline After_tax & $\begin{array}{c}-0.186 \\
{[1.525]}\end{array}$ & $\begin{array}{c}-0.359 \\
{[0.124]^{* *}}\end{array}$ & $\begin{array}{c}0.738 \\
{[1.208]}\end{array}$ & $\begin{array}{c}-1.412 \\
{[2.798]}\end{array}$ \\
\hline NFundsOffered & $\begin{array}{c}1.177 \\
{[0.299]^{* *}}\end{array}$ & $\begin{array}{c}0.017 \\
{[0.024]}\end{array}$ & $\begin{array}{c}0.325 \\
{[0.225]}\end{array}$ & $\begin{array}{c}1.225 \\
{[0.529]^{*}}\end{array}$ \\
\hline NFunds_sq & $\begin{array}{c}-0.02 \\
{[0.006]^{* *}}\end{array}$ & $\begin{array}{c}-0.0001 \\
{[0.0004]}\end{array}$ & $\begin{array}{c}-0.006 \\
{[0.004]} \\
\end{array}$ & $\begin{array}{c}-0.015 \\
{[0.009]}\end{array}$ \\
\hline Fund_stock & $\begin{array}{c}-0.125 \\
{[0.055]^{*}}\end{array}$ & $\begin{array}{c}0.001 \\
{[0.004]} \\
\end{array}$ & $\begin{array}{c}0.017 \\
{[0.046]} \\
\end{array}$ & $\begin{array}{c}-0.054 \\
{[0.104]} \\
\end{array}$ \\
\hline ER_stock & $\begin{array}{c}1.163 \\
{[1.746]}\end{array}$ & $\begin{array}{c}-0.125 \\
{[0.153]}\end{array}$ & $\begin{array}{c}1.801 \\
{[1.282]}\end{array}$ & $\begin{array}{l}-0.668 \\
{[3.000]}\end{array}$ \\
\hline Loan & $\begin{array}{c}0.065 \\
{[2.207]} \\
\end{array}$ & $\begin{array}{c}0.597 \\
{[0.192]^{* *}} \\
\end{array}$ & $\begin{array}{c}0.445 \\
{[1.938]}\end{array}$ & $\begin{array}{l}-0.206 \\
{[3.865]}\end{array}$ \\
\hline \multicolumn{5}{|c|}{ EMPLOYER CHARACTERISTICS } \\
\hline Plan_size & $\begin{array}{c}-3.621 \\
{[0.507]^{* *}}\end{array}$ & $\begin{array}{c}-0.068 \\
{[0.046]}\end{array}$ & $\begin{array}{l}-0.896 \\
{[0.630]}\end{array}$ & $\begin{array}{c}-4.099 \\
{[0.975]^{* *}}\end{array}$ \\
\hline $\mathrm{DB}$ & $\begin{array}{c}-2.021 \\
{[1.608]} \\
\end{array}$ & $\begin{array}{c}0.054 \\
{[0.121]} \\
\end{array}$ & $\begin{array}{c}-1.161 \\
{[1.769]} \\
\end{array}$ & $\begin{array}{c}-1.466 \\
{[2.806]}\end{array}$ \\
\hline$\overline{\mathrm{DC}}$ & $\begin{array}{c}-0.946 \\
{[1.283]} \\
\end{array}$ & $\begin{array}{c}-0.204 \\
{[0.107]} \\
\end{array}$ & $\begin{array}{l}-0.856 \\
{[1.043]}\end{array}$ & $\begin{array}{c}-3.69 \\
{[2.372]} \\
\end{array}$ \\
\hline \multicolumn{5}{|c|}{ EMPLOYEE CHARACTERISTICS } \\
\hline Mean_age & $\begin{array}{c}0.242 \\
{[0.235]}\end{array}$ & $\begin{array}{c}0.038 \\
{[0.022]} \\
\end{array}$ & $\begin{array}{c}0.213 \\
{[0.201]} \\
\end{array}$ & $\begin{array}{c}-0.021 \\
{[0.359]} \\
\end{array}$ \\
\hline Mean_comp & $\begin{array}{c}0.534 \\
{[0.072]^{* *}}\end{array}$ & $\begin{array}{c}0.058 \\
{[0.007]^{* *}}\end{array}$ & $\begin{array}{c}-0.01 \\
{[0.011]}\end{array}$ & $\begin{array}{c}0.057 \\
{[0.024]^{*}}\end{array}$ \\
\hline Mean_tenure & $\begin{array}{c}0.565 \\
{[0.216]^{* *}} \\
\end{array}$ & $\begin{array}{c}0.034 \\
{[0.022]} \\
\end{array}$ & $\begin{array}{c}-0.02 \\
{[0.188]} \\
\end{array}$ & $\begin{array}{c}-0.281 \\
{[0.311]}\end{array}$ \\
\hline Female_pct & $\begin{array}{c}0.149 \\
{[0.036]^{* *}}\end{array}$ & $\begin{array}{c}-4.2 \mathrm{E}-6 \\
{[0.003]}\end{array}$ & $\begin{array}{c}-0.063 \\
{[0.085]}\end{array}$ & $\begin{array}{c}0.128 \\
{[0.110]}\end{array}$ \\
\hline Constant & $\begin{array}{c}42.885 \\
{[11.184]^{* *}}\end{array}$ & $\begin{array}{c}2.073 \\
{[1.011]^{*}}\end{array}$ & $\begin{array}{c}78.938 \\
{[11.105]^{* *}}\end{array}$ & $\begin{array}{c}49.56 \\
{[19.547]^{*}} \\
\end{array}$ \\
\hline $\begin{array}{l}\text { Observations } \\
\text { R-squared }\end{array}$ & $\begin{array}{l}507 \\
0.39\end{array}$ & $\begin{array}{c}506 \\
0.3\end{array}$ & $\begin{array}{l}474 \\
0.11\end{array}$ & $\begin{array}{l}472 \\
0.19\end{array}$ \\
\hline
\end{tabular}

Notes: $*$ significant at 5\%; ** significant at $1 \%$. Robust standard errors in brackets. Industry controls included. 
Table 5: Overview of Observed Employee Behaviors

Panel A. Responsiveness of NHCE Participation and Savings Rates

\begin{tabular}{|c|c|}
\hline Change in Design & Change in Match Design \\
\hline $\begin{array}{c}\text { Increase in match rate on first 3\% by } \\
\$ 0.10-\text { from } \$ 0.55 \text { to } \$ 0.65\end{array}$ & $0.8 \%$ point increase in NHCE participation rate; \\
\hline Doubling of match rate on first 3\%-- & $0.07 \%$ point decrease in NHCE savings rate \\
\hline from $\$ 0.55$ to $\$ 1.10$ & $5.4 \%$ point increase in NHCE participation rate; \\
Adding 2 funds to plan & $0.2 \%$ point decrease in NHCE savings rate \\
\hline $\begin{array}{c}\text { Increasing equity funds from } 65 \% \text { to } \\
75 \% \text { of menu }\end{array}$ & \begin{tabular}{c}
$1.5 \%$ point increase in NHCE participation rate \\
\hline Adding a loan
\end{tabular} \\
\hline
\end{tabular}

Panel B. Variation in NHCE Participation Rate Based on Match Design

Forecast value of NHCE participation rate based on match design, with all other independent variables estimated at means.

Base participation rate (no match, no loan): $63 \%$

Base participation rate (no match, with loan): $64 \%$

Match rates

\begin{tabular}{|r|r|r|r|}
\hline Match tier & $\begin{array}{c}\text { \$0.25 on the } \\
\text { dollar }\end{array}$ & $\begin{array}{c}\text { \$0.50 on the } \\
\text { dollar }\end{array}$ & $\begin{array}{c}\text { \$1.00 on the } \\
\text { dollar }\end{array}$ \\
\hline $3 \%$ & $69 \%$ & $71 \%$ & $76 \%$ \\
\hline $4 \%$ & $69 \%$ & $72 \%$ & $77 \%$ \\
\hline $5 \%$ & $70 \%$ & $73 \%$ & $78 \%$ \\
\hline $6 \%$ & $71 \%$ & $73 \%$ & $78 \%$ \\
\hline
\end{tabular}

Panel C. Variation in NHCE Savings Rate Based on Match Design

Forecast value of NHCE savings rate based on match design, with all independent variables estimated at means.

Base savings rate (no match, no loan): $6.1 \%$

Base savings rate (no match, with loan): $6.7 \%$

Match rates

\begin{tabular}{|c|c|c|c|}
\hline Match tier & $\begin{array}{c}\text { \$0.25 on the } \\
\text { dollar }\end{array}$ & $\begin{array}{c}\text { \$0.50 on the } \\
\text { dollar }\end{array}$ & $\begin{array}{c}\text { \$1.00 on the } \\
\text { dollar }\end{array}$ \\
\hline $3 \%$ & $6.6 \%$ & $6.5 \%$ & $6.3 \%$ \\
\hline $4 \%$ & $6.6 \%$ & $6.5 \%$ & $6.3 \%$ \\
\hline $5 \%$ & $6.6 \%$ & $6.5 \%$ & $6.3 \%$ \\
\hline $6 \%$ & $6.6 \%$ & $6.5 \%$ & $6.3 \%$ \\
\hline
\end{tabular}


Table 6. Relationship between Plan Design and Employer Expenditures for Matching Contributions (as a Percent of Compensation)

\begin{tabular}{|c|c|}
\hline & $\frac{\text { ER Expenditures as \% of }}{\text { Compensation }}$ \\
\hline \multicolumn{2}{|c|}{ PLAN ATTRIBUTES } \\
\hline Match_f3 & $\begin{array}{c}0.015 \\
{[0.002]^{* *}}\end{array}$ \\
\hline Match_n3 & $\begin{array}{c}0.021 \\
{[0.002]^{\star *}}\end{array}$ \\
\hline Match_n2 & $\begin{array}{l}-0.0003 \\
{[0.004]} \\
\end{array}$ \\
\hline Contr4MaxMatch & $\begin{array}{c}0.01 \\
{[0.016]}\end{array}$ \\
\hline After_tax & $\begin{array}{c}0.049 \\
{[0.083]}\end{array}$ \\
\hline NFundsOffered & $\begin{array}{l}-0.006 \\
{[0.016]}\end{array}$ \\
\hline NFunds_sq & $\begin{array}{c}0.0002 \\
{[0.0003]}\end{array}$ \\
\hline Fund_stock & $\begin{array}{c}0.001 \\
{[0.002]}\end{array}$ \\
\hline ER_stock & $\begin{array}{c}-0.009 \\
{[0.134]}\end{array}$ \\
\hline Loan & $\begin{array}{c}0.266 \\
{[0.093]^{* *}}\end{array}$ \\
\hline \multicolumn{2}{|c|}{ EMPLOYER CHARACTERISTICS } \\
\hline Plan_size & $\begin{array}{c}-0.108 \\
{[0.030]^{\star *}}\end{array}$ \\
\hline$\overline{\mathrm{DB}}$ & $\begin{array}{c}0.038 \\
{[0.072]}\end{array}$ \\
\hline$\overline{\mathrm{DC}}$ & $\begin{array}{l}-0.127 \\
{[0.065]}\end{array}$ \\
\hline \multicolumn{2}{|c|}{ EMPLOYEE CHARACTERISTICS } \\
\hline Mean_age & $\begin{array}{c}0.024 \\
{[0.012]}\end{array}$ \\
\hline Mean_tenure & $\begin{array}{l}-0.016 \\
{[0.013]}\end{array}$ \\
\hline Female_pct & $\begin{array}{c}0.003 \\
{[0.002]}\end{array}$ \\
\hline Constant & $\begin{array}{l}-0.501 \\
{[0.510]}\end{array}$ \\
\hline $\begin{array}{l}\text { Observations } \\
\text { R-squared }\end{array}$ & $\begin{array}{l}507 \\
0.76\end{array}$ \\
\hline
\end{tabular}

Notes:* significant at 5\%; ** significant at $1 \%$. Robust standard errors in brackets. Industry controls included. 


\section{Table 7. Summary of Employer Plan Matching Expenditures}

Panel A. Responsiveness of Employer Plan Matching Expenditures

\begin{tabular}{|l|c|}
\hline Plan Feature & $\begin{array}{l}\text { Change in ER Expenditures } \\
\text { (as \% of Compensation) }\end{array}$ \\
\hline $\begin{array}{l}+10 \text { cents match on first 3\% of pay: } \\
\text { from } \$ 0.55 \text { to } \$ 0.65\end{array}$ & $+8 \%$ \\
\hline $\begin{array}{l}+10 \text { cents match on the next 3\% of } \\
\text { pay: from } \$ 0.37 \text { to } 0.47\end{array}$ & $+12 \%$ \\
\hline Offers loan & $+15 \%$ \\
\hline
\end{tabular}

Panel B. Variation in Employer Expenditures Based on Match Design

Forecast value of employer match costs (as a percent of payroll), with all independent variables estimated at means except for match variables

Match rates

\begin{tabular}{|r|r|r|r|}
\hline Match tier & $\begin{array}{c}\text { \$0.25 on the } \\
\text { dollar }\end{array}$ & $\begin{array}{c}\text { \$0.50 on the } \\
\text { dollar }\end{array}$ & $\begin{array}{c}\text { \$1.00 on the } \\
\text { dollar }\end{array}$ \\
\hline $3 \%$ & $0.25 \%$ & $0.63 \%$ & $1.38 \%$ \\
\hline $4 \%$ & $0.44 \%$ & $0.99 \%$ & $2.09 \%$ \\
\hline $5 \%$ & $0.62 \%$ & $1.35 \%$ & $2.80 \%$ \\
\hline $6 \%$ & $0.81 \%$ & $1.71 \%$ & $3.51 \%$ \\
\hline
\end{tabular}


Figure 1. Distribution of Employer Match Patterns in Single-Formula Plans (360 Plans)

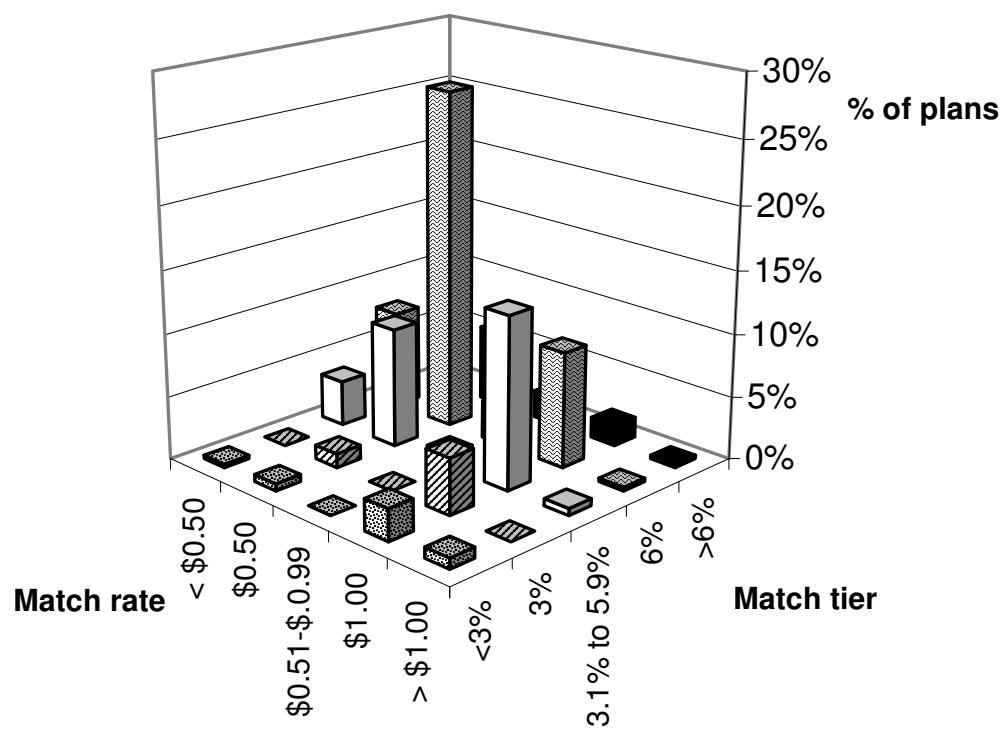

Figure 2. Distribution of Maximum Employer Match Rates in Single-Formula Plans (360 Plans)

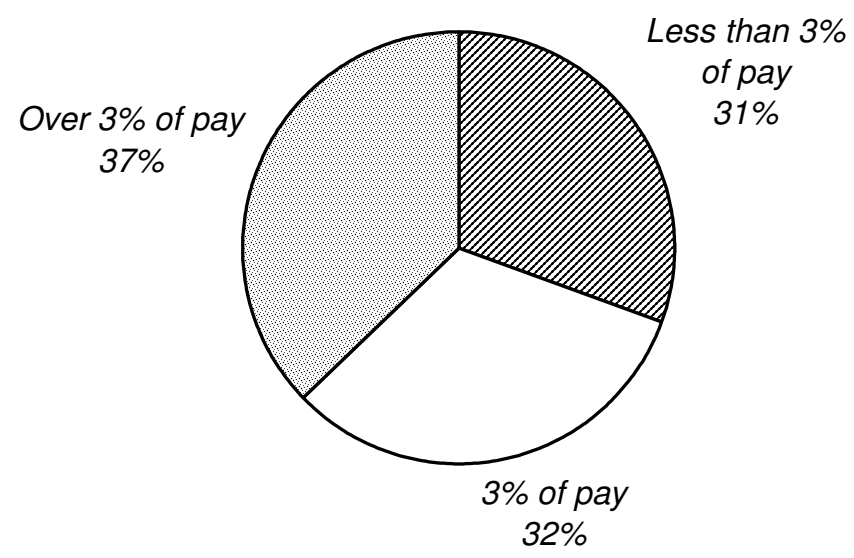


Figure 3. Incentive Effect of the Employer Match on Non Highly Compensated Employees (NHCE)

Panel A. Impact of Match and Loan on Participation (at sample means)

Predicted NHCE Plan Participation Rate

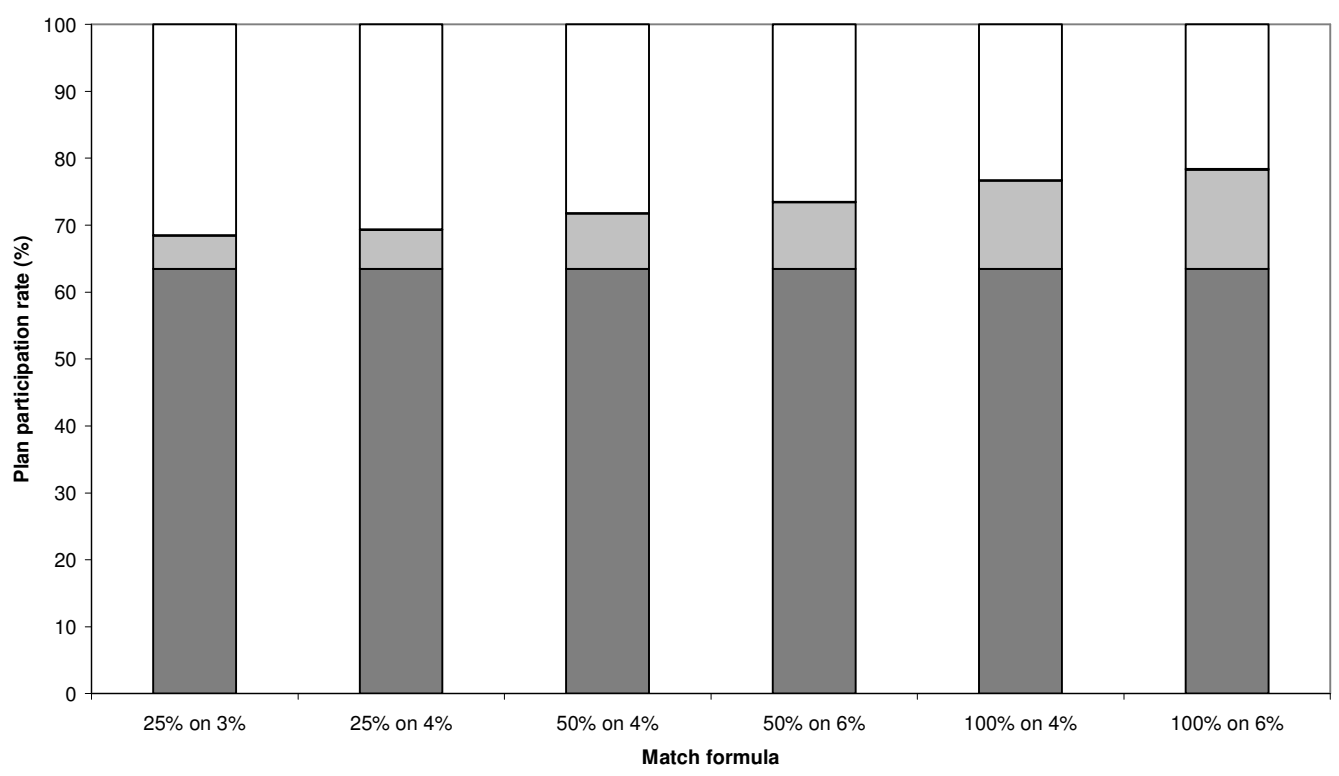

$\square$ Participation with no match, no loan $\quad \square$ Effect of match $\quad \square$ Effect of loan $\quad \square$ Non-participants

Panel B. Impact of Match and Loan on Contribution Rate (at sample means)

Predicted NHCE Saving Rate

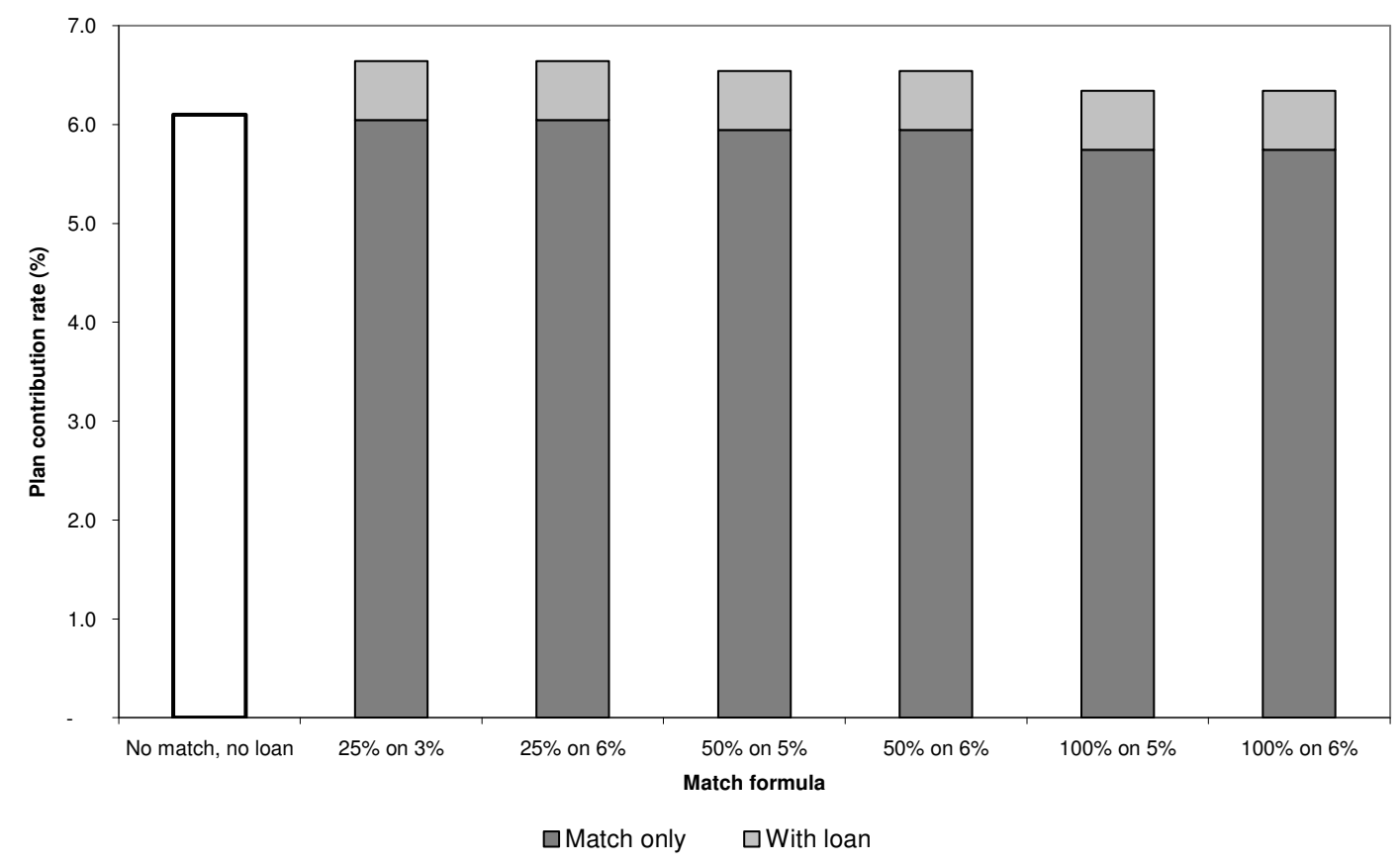


Figure 4. Implicit Discount Rates in 401(k) Match Formulas

Implicit Discount Rates in 401(K) Match Design

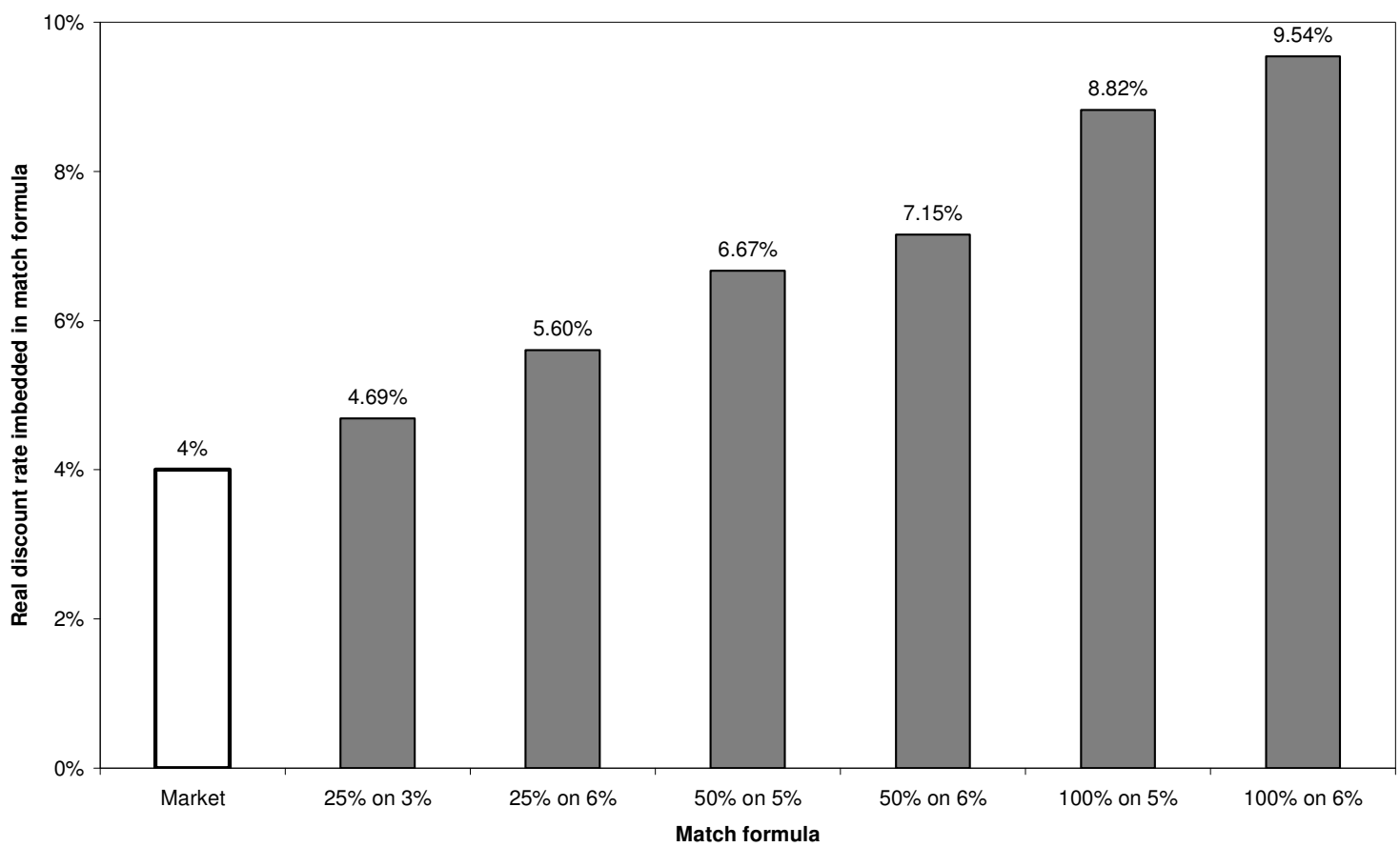

Figure 5. Impact on Employer Matching Costs of Match and Loans (at sample means)

Design Impact on Employer Matching Costs

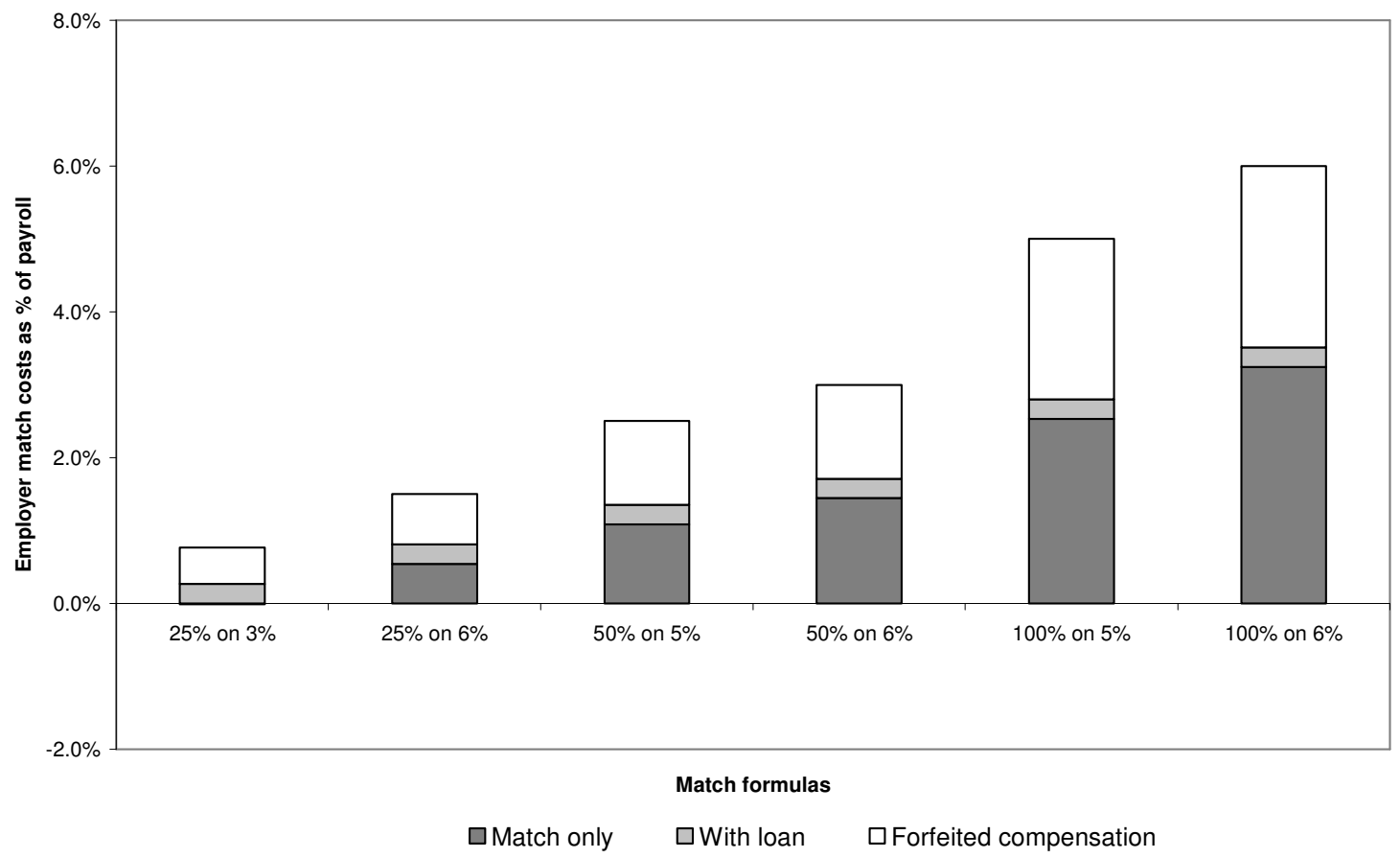




\section{References}

Agnew, Julie, Pierluigi Balduzzi, and Annika Sundén. 2003. "Portfolio Choice and Trading in a Large 401(k) Plan." The American Economic Review. 93(1): 193-215.

Ameriks, John, Andrew Caplin, John Leahy, Tom Tyler. "Measuring Self-Control.” NBER Working Paper 10514. www.nber.org

Ameriks, John, and Stephen P. Zeldes. 2001. "How Do Household Portfolio Shares Vary With Age?” TIAA-CREF Institute working paper 6-120101.

Andrews, Emily S. 1992. “The Growth and Distribution of 401(k) Plans.” In John Turner and Daniel Beller, eds., Trends in Pensions 1992. Washington, DC: US Department of Labor. 149-176.

Benartzi, Shlomo, Richard H. Thaler, Stephen P. Utkus and Cass R. Sunstein. 2004. "Company Stock, Market Rationality and Legal Reform.” University of Chicago Law and Economics Olin School Working Paper 218. www.ssrn.com.

Choi, James J., David Laibson, and Brigitte C. Madrian. 2004 "Plan Design and 401(k) Saving Outcomes.” National Tax Journal. Forum on Pensions.

Choi, James J., David Laibon, Brigitte Madrian, and Andrew Metrick. (Forthcoming). "Saving for Retirement on the Path of Least Resistance." In Behavioral Public Finance, Eds Ed McCaffrey and Joel Slemrod.

Clark, Robert L. and Sylvester Schieber. 1998. "Factors Affecting Participation Levels in 401(k) Plans." In Living with Defined Contribution Plans: Remaking Responsibility for Retirement, Olivia Mitchell and Sylvester J. Schieber, eds. Philadelphia, PA: University of Pennsylvania Press: 69-97.

Cunninghan, Christopher R. and Gary V. Engelhardt. 2002. "Federal Tax Policy, Employer Matching, and 401(k) Saving: Evidence from HRS W-2 Records." National Tax Journal. 55(3). September: 617-645.

Elton, Edwin J., Martin J. Gruber and Christopher R. Blake. 2004. “The Adequacy of Investment Choices Offered by 401(k) Plans.” Stern School Working Paper, New York University,

Engelhardt, Gary V. and Anil Kumar. 2003. "Understanding the Impact of Employer Matching on 401(k) Saving." Research Dialogue 76. TIAA CREF Institute. June. www.tiaa-crefinstitute.org.

Engelhardt, Gary V. and Anil Kumar. 2004. "Employer Matching and 401(k) Saving: Evidence from the Health and Retirement Study." Maxwell School Working Paper. Syracuse University.

Even, William E., and David A. Macpherson. 1997. "Factors Influencing Participation and Contribution Levels in 401(k) Plans." Florida State University Working Paper. Tallahassee, FL: Florida State University.

Even, William E., and David A. Macpherson. 2003. "Determinants and Effects of Employer Matching Contributions in 401(k) Plans.” Florida State University Working Paper. Tallahassee, FL: Florida State University.

Holden, Sarah, and Jack VanDerhei. 2001. "Contribution Behavior of 401(k) Plan Participants", ICI Perspective, October.

Holden, Sarah, and Jack VanDerhei. 2005. "The Role of 401(k) Accumulations in Providing Future Retirement Income." Pension Research Council Working Paper 2005-9. http://rider.wharton.upenn.edu/ prc/wp2005.html

Huberman, Gur, Sheena Iyengar, and Wei Jiang. 2004. "Defined Contribution Pension Plans: Determinants of Participation and Contribution Rates." Columbia University Business School Working Paper.

Iyengar, Sheena, Gur Huberman, and Wei Jiang. 2004. "How Much Choice is Too Much? Contributions to 401(k) Retirement Plans.” In Pension Design and Structure: New Lessons from Behavioral Finance. Olivia S. Mitchell and Stephen P. Utkus, eds. Oxford, United Kingdom: Oxford University Press: 83-95.

Jiang, Wei and Sheena S. Iyengar. Forthcoming. "The Psychological Costs of Ever Increasing Choice: A Fallback to the Sure Bet." Journal of Personality and Social Psychology.

Kusko, Andrea, James Poterba and David Wilcox. 1998. "Employee Decisions with Respect to 401(k) Plans." In Living with Defined Contribution Pensions: Remaking Responsibility for Retirement, Olivia Mitchell and Sylvester Schieber, eds. Philadelphia, PA: University of Pennsylvania Press. 98-112. 
Madrian, Brigitte, and D.F. Shea. 2001. "The Power of Suggestion: Inertia in 401(k) Participation and Savings Behavior." Quarterly Journal of Economics 116: 1149-1525.

McGill, Dan, Kyle Brown, John Haley and Sylvester Schieber. Fundamentals of Private Pensions $8^{\text {th }}$ ed. Oxford: Oxford University Press, 2004.

Mitchell, Olivia S. and Stephen P. Utkus. 2003. "Company Stock in Defined Contribution Plans." In The Pension Challenge: Risk Transfers and Retirement Income Security, Olivia S. Mitchell and Kent Smetters, eds. Oxford, United Kingdom: Oxford University Press: 33-70.

Munnell, Alicia, Annika Sunden, and Catherine Taylor. 2000. "What Determines 401(k) Participation and Contributions?" Center for Retirement Research Working Paper 2000-12. Boston, MA: Boston College.

Munnell, Alicia H. and Annika Sunden. 2004. Coming Up Short. Washington, DC: Brookings Institution Press.

Papke, Leslie. 1995. "Participation in and Contributions to 401(k) Pension Plans: Evidence from Plan Data." Journal of Human Resources. 30. 311-325.

Papke, Leslie and James M. Poterba. 1995. "Survey Evidence on Employer Match Rates and Employee Saving Behavior in 401(k) Plans." Economics Letters. 49. 313-317.

Pence, Karen. 2002. "Nature or Nurture: Why Do 401(k) Participants Save Differently than Other Workers?" National Tax Journal, 55 (September). 597-616.

Poterba, James, Steve Venti and David Wise. 2004. "The Transition to Personal Accounts and Increasing Retirement Wealth: Macro and Micro Evidence." In D. Wise, ed., Perspectives on the Economics of Aging, Chicago, IL: Chicago University Press: 17-71.

Profit-Sharing / 401(k) Council of America. 2004. 47 ${ }^{\text {th }}$ Annual Survey of Profit Sharing and 401(k) Plans: Reflecting 2003 Plan Year Experience. Chicago, IL: Profit-Sharing / 401(k) Council of America. www.psca.org.

US Department of Labor. (USDOL) 2004. National Compensation Survey: Employee Benefits in Private Industry in the United States, 2000. U.S. Department of Labor. Washington, DC. http://www.bls.gov/ncs/ebs/ sp/ebbl0019.pdf.

US General Accounting Office (USGAO). 1997. “401(k) Pension Plans: Loan Provisions Enhance Participation, but May Affect Income Security for Some.” U.S. General Accounting Office: Washington. DC. GAO/HEHS-985.October.

VanDerhei, Jack and Craig Copeland. 2001. “A Behavioral Model for Predicting Employee Contributions to 401(k) Plans: Preliminary Results." North American Actuarial Journal. 5(1): 80-94.

The Vanguard Group. 2004. How America Saves, 2004: A Report on Vanguard Defined Contribution Plans. Malvern, PA: Vanguard Center for Retirement Research. September. www.vanguardretirementresearch.com. 